\title{
Escola: uma tatuagem nas memórias
}

Ilse Leone B. C. de Oliveira*

\section{Resumo}

Este trabalho fundamenta-se nos pressupostos da Análise do Discurso de linha francesa. Nele, sirvo-me da metáfora da tatuagem para demonstrar como os enunciados pigmentam as memórias escolares de três autores, ao evocarem suas lembranças em textos de caráter autobiográfico. Analiso esses textos sob a perspectiva da autobiografia, da escrita de si e da autodesignação. Interessa-me investigar, problematizando, as condiçóes sócio-históricas que possibilitam e/ou que determinam que sejam esses os enunciados produzidos, e não outros. Palavras-chave: escola, memória, autobiografia.

School: a tatoo of memories

\begin{abstract}
This paper is based on presuppositions of French Discourse Analysis. In it the metaphor of a tattoo is used to demonstrate how utterances color the school memories of three authors, as they evoke their memories in autobiographic texts. These texts are analyzed from the perspective of autobiography, writing about oneself and self-designation. The study sets out to investigate and at the same time problematize the socio-historical conditions, which make possible and/or determine that one particular text is produced and not another.
\end{abstract}

Keywords: school, memories, autobiography.

\section{Apresentação}

Este texto não se inscreve na categoria de histórico, sociológico e, provavelmente, não se caracterize como um texto da área da linguística nem da literatura. Como um texto fundamentado na Análise do Discurso de

* Uma primeira versão deste texto foi apresentada no IX Encontro Nacional de Interação e Linguagem, na UFPB, em 22 set. 2010, com publicação eletrônica ainda a ser lançada.

** Professora Mestre do Cepae/UFG, Subárea de Português. E-mail: ilseleone@yahoo.com.br. 
linha francesa, mais precisamente de vertente foucaultiana, minha pretensão é apenas e tão-somente problematizar, na dispersão discursiva que atravessa e entrelaça todas essas áreas de conhecimento, a memória escolar inscrita em narrativas de caráter autobiográfico. Assim, por um lado, entreteço enunciados de autores diversos que, ainda que sob um rigor teórico pareçam náo dialogar entre si, compóem parte da trama que materializa discursos sobre memória, autobiografia, escola e educação; por outro, faço referência a autores como Montessori, Pestalozzi, Piaget, Richmond, não porque deem suporte teórico à discussão que proponho, mas porque produziram discursos que determinaram e até hoje determinam formas de pensar e praticar a pedagogia e a educação. $\mathrm{O}$ que interessa, portanto, à problematização que proponho são os discursos, seus entrelaçamentos, suas entredeterminaçóes e as práticas discursivas e não discursivas deles decorrentes.

Ousei, assumindo o risco de não alcançar êxito, olhar para esses discursos na perspectiva de Foucault (2004, p. 28), quando anuncia que

[...] é preciso estar pronto para acolher cada momento do discurso em sua irrupçáo de acontecimentos, nessa pontualidade em que aparece e nessa dispersão temporal que lhe permite ser repetido, sabido, esquecido, transformado, apagado até nos menores traços, escondido bem longe de todos os olhares, na poeira dos livros. Não é preciso remeter o discurso à longínqua presença da origem; é preciso tratá-lo no jogo de sua instância.

É no jogo de sua instância e nas condições de sua emergência que olho para os discursos. Assumindo essa posição, resguardo-me do risco de que este texto se constitua uma história da educação, traçada por meio da análise que empreendo das narrativas memorialísticas, de caráter autobiográfico, de três autores. Não busco a origem desses discursos para encadeá-los num processo histórico, mas procuro percorrer, na dispersão temporal, a superfície da trama que entretecem, com o propósito de investigar como as memórias se materializam discursivamente.

\section{A escola é um lugar de memória}

Souza (2000, p. 7) afirma que "a escola é um lugar de memória” e que o inventário e a evolução dos espaços, das práticas e técnicas escolares constituem um dos mais interessantes objetos da história dessa institui- 
ção. Construindo um pouco dessa memória, a referida autora perpassa a organização de uma sala de aula do início do século XX. Evidencia ela que essa organização define os lugares dos sujeitos, conforme a posição que ocupem:

Dominando a sala, a escrivaninha do professor, eixo do saber, símbolo da autoridade social. Atrás do mestre, o quadro-negro, onde se inscreviam a data e a lição do dia. Em cima do quadro, o retrato de um republicano; ao lado da bandeira, os mapas. Diante da parede do conhecimento, alinhados em cinco ou seis fileiras paralelas, as carteiras arrumavam silenciosamente os alunos. Cada um sabia quem era pelo lugar que o professor ou professora o colocava, cabendo a cada um merecer seu lugar no espaço magistral: assim se explicava a cerimônia periódica da troca dos lugares. Os bons alunos, os razoáveis ou apenas os tímidos (depois foi a vez dos maus) beneficiavam-se dos primeiros lugares, perto do quadro-negro e das explicaçóes, longe da dissipação, mas também das inquietações das últimas fileiras. (SOUZA, 2000, p. 8)

Postula a referida autora que, assim como a organizaçáo espaço-ideológica da sala de aula, as práticas e técnicas escolares condicionaram os alunos a uma memória tecida em função de perspectivas. A escola é reconhecida como espaço de normalização sociocultural, que visa a diminuir idiossincrasias e atenuar personalidades, servindo-se de práticas de estimulação (a classificação, os prêmios) e de reprovação (a palmatória, as orelhas de burro, as notas). Entretanto, não fosse ela palco para o enfrentamento dessas práticas e dos conflitos delas decorrentes, tem-se a impressão de que não haveria memórias a construir.

Souza (2000, p. 11) lembra que "a escola pública vem de uma tradição, datada da revolução industrial, de que a vida é uma coisa séria, minuto a minuto, lição por lição, tostâo por tostão, tarefa por tarefa: honra ao mérito". No entanto, mantém-se dessa escola uma saudade paradoxal, porque ela era clara em seus limites, demonstrava que o ensino e a cultura não são naturais e que não se atinge o conhecimento sem esforço e sacrifício. É como se a "violência pedagógica" fosse necessária para que a filosofia, as ciências, a literatura, a matemática, a história subsistissem. Além disso, foi nos limites da cultura escolar que se criou uma outra cultura, "apesar da escola, contra a escola, fora da escola, mas dependendo dela” (SOUZA, 2000, p. 11). Dentro dessa outra cultura, os que sobreviveram à escola tradicional 
fizeram vicejar a crítica, a contracultura, a rebelião e o humor. Uma questáo importante que Souza propóe, entretanto, é como poderíamos, hoje, ter nostalgia da escola e rir dela, se as condiçôes atuais de ensino fizeram o humor do fundo das salas degenerar em barbárie?

Por barbárie, deve-se entender a violência e a falta de segurança que adentrou, nos últimos anos, os muros da escola e as paredes da sala de aula. Essa barbárie que não é, portanto, produção exclusivamente do ambiente intraescolar, nos faz refletir acerca da crise do sistema de ensino público brasileiro. Por um lado, a necessidade da democratização do ensino vem já há mais de meio século, no Brasil, ampliando o número de escolas, de vagas nas escolas; vem promovendo, por meio de programas sociais, o acesso e a permanência dos alunos nas escolas. Por outro, a complexidade social contemporânea e a modernização tecnológica entra em choque com o conservadorismo da escola tradicional, comprometendo profundamente a qualidade do ensino e corroendo a identidade do professor.

A relação que Halbwachs estabelece entre identidade e memória se faz, então, importante para o propósito deste trabalho. Não sendo a nossa memória uma tábula rasa, sentimo-nos "capazes, por nossas próprias forças, de perceber, como num espelho turvo, alguns traços e alguns contornos (talvez ilusórios) que nos devolveriam a imagem do passado" (HALBWACHS, 1990, p. 28). Na imagem do nosso passado educacional, quem sabe possam ser vislumbradas as raízes da crise atual da escola. Vislumbrá-las não significa, certamente, encontrar soluçôes para os problemas, mas quem sabe signifique a possibilidade de compreendê-los.

Para fazer o retorno a esse passado referente à memória escolar, sirvo-me de alguns textos, alguns enunciados produzidos por autores em situação de rememoração. Tento empreender uma análise do campo discursivo que, conforme Foucault (2004, p. 31), trata de

[...] compreender o enunciado na estreiteza e singularidade de sua situação; de determinar as condiçóes de sua existência, de fixar seus limites da forma mais justa, de estabelecer suas correlaçôes com outros enunciados a que pode estar ligado, de mostrar que outras formas de enunciação exclui.

Interessa-me investigar, problematizando, as condições sócio-históricas que possibilitaram ou que determinaram que fossem esses os enunciados produzidos, e não outros. 


\section{Autobiografia e testemunho: a escola tatuada nas memórias}

Os textos a que me reporto são os fragmentos de dois poemas de Cora Coralina (2004), Menina mal amada e Mestra Silvina, o romance Doidinho, de José Lins do Rego (1994), e uma produção escolar, da aluna Alice, que compóe o corpus de dados da pesquisa que desenvolvo no doutorado. Lembro que a autora deste último texto e a escola em que estuda terão suas identidades preservadas por nomes fictícios. A escolha dos poemas de Cora Coralina e do livro de José Lins do Rego se deu pelo fato de terem sido lidos, analisados, discutidos com meus alunos de $7^{\circ}$ ano em um trabalho que desenvolvemos sobre memória escolar. Quanto ao texto de Alice, eu o escolhi, primeiro, porque era meu interesse incluir nesta reflexão uma produção de aluno; segundo, porque seria o contraponto aos outros dois textos: a memória de uma escola do final do século XX. Além disso, pareceu-me producente para este trabalho atribuir à aluna a função de autora (FOUCAULT, 1992), colocando-a lado a lado com dois autores consagrados, de forma que seu texto saltasse da condição insípida de produção escolar para a condição de texto que foi publicado, lido, discutido. A narrativa de Alice foi selecionada entre as de outros dez alunos. O critério para a seleçấo foi aleatório, uma vez que qualquer um dos outros dez atenderia ao meu propósito.

Sirvo-me da figura da tatuagem porque, em cada um dos fragmentos citados, os enunciados vão pigmentando as memórias com emoçóes de diversas tonalidades, compondo em imagens as evocaçóes dos autores. Ainda que fragmentos, considero importante citá-los em sua unidade de significação, porque assim o leitor deste artigo pode deixar-se envolver pelas memórias de Cora Coralina, de José Lins do Rego e de Alice, antes de ser atravessado pelo discurso que, também atravessado por tantos outros discursos, produzi sobre elas. São estes os fragmentos:

Muito me valeu a escola.

Um dia, certo dia, a mestra se impacientou.

Gaguejava a lição, truncava tudo. Não dava mesmo.

A mestra se alterou de todo, perdeu a paciência,

e mandou enérgica: estende a máo.

Ela se fez gigante no meu medo maior, sem tamanho.

Mandou de novo: estende a máo.

Eu de medo encolhia o braço. 
Estende a mão! Mão de Aninha, tão pequena!

A meninada, pensando nalguns avulsos para eles,

Nem respirava, intimidada.

Tensa, espectante, repassada.

Era sempre assim na hora dos bolos em máos alheias.

Aninha, estende a mão. Mão de Aninha, tão pequena.

A palmatória cresceu no meu medo, seu rodelo se fez maior,

$\mathrm{O}$ cabo se fez cabo de machado, a mestra se fez gigante

e o bolo estralou na pequena mão obediente.

Meu berro! e a mijada incontinente, irreprimida.

Só? Não. O coro do banco dos meninos, a vaia impiedosa.

- Mijou de medo... Mijou de medo... Mijou de medo...

A mestra bateu a régua na mesa, enfiou a palmatória na gaveta,

e, receosa de piores conseqüências, me mandou pra casa, toda mijada, sofrida, humilhada, soluçando, a mão em fogo.

(CORALINA, 2004, p. 117-118)

Minha escola primária, fostes meu ponto de partida,

dei voltas ao mundo.

Criei meus mundos...

Minha escola primária. Minha memória reverencia minha velha Mestra.

$[\ldots]$

Minha escola primária...

Eu era um casulo feio, informe, inexpressivo.

E ela me refez, me desencantou.

Abriu pela paciência e didática da velha mestra,

cinquentanos mais do que eu, o meu entendimento ocluso.

A escola da Mestra Silvina...

Tão pobre ela. Tão pobre a escola...

Sua pobreza encerrava uma luz que ninguém via.

Tantos anos já corridos...

Tantas voltas deu-me a vida...

[...]

Toda pobreza da minha velha escola

se impóe e a mestra é iluminada de uma nova dimensão.

(CORALINA, 2004, p. 124 -125)

- Pode deixar o menino sem cuidados. Aqui eles endireitam, saem feitos gente - dizia um velho alto e magro para o meu tio Juca, que me levara para o colégio de Itabaiana. Estávamos na sala de visitas. Eu, encolhido numa cadeira, todo enfiado para um canto, o meu tio Juca e o mestre. Queria este 
saber de minha idade, do meu adiantamento. Meu tio informava tudo: 12 anos, segundo livro de Felisberto de Carvalho, tabuada de multiplicar.

[...]

O colégio de Itabaiana criara fama pelo seu rigorismo. Era uma espécie de último recurso para meninos sem jeito. $\mathrm{O}$ Diocesano não me aceitara porque estava de matrícula encerrada. Lembraram-se do colégio de seu Maciel, como era conhecido nos arredores o Instituto Nossa Senhora do Carmo. Lá estiveram os meus primos uns dois anos. Voltaram contando as mais terríveis histórias do diretor. Um judeu. Dava sem pena de palmatória, por qualquer coisa. Era ali onde estava agora.

[...]

- Tem um velho na sala de visitas lhe esperando.

Corri ansioso para lá. Beijei a mâo cheia de veias do velho Zé Paulino. Já estava em conversas com o diretor:

- Náo me importo que dê no menino. Botei aqui para aprender, e menino só aprende mesmo é com castigo. Agora o que não admito é judiação. Isto não. Prefiro deixar na bagaceira. Isto não.

- Não há judiação, coronel. Só castigo quando há precisão. Pelo meu colégio tem passado muita gente e todos ficam meus amigos. O senhor está mal informado. Não vá atrás de cartas de aluno. $\mathrm{O}$ que eles querem é vadiar, e mentem, e inventam. Luto há cinqüenta anos com essa gente.

[...]

O velho Maciel tinha razão. Em pouco tempo adiantara-me bastante. O medo do bolo vencera o rude da d. Sinhazinha. Estava nas fraçóes e quase no fim do terceiro livro de leitura. A letra, porém, é que não tinha jeito de melhorar. O meu nervoso talvez fosse o responsável pelos meus garranchos. Cobria com cuidado os cadernos de caligrafia, e borrôes ficavam em cada página.

- Se este caderno vier borrado amanhã, o senhor se arrepende.

E ia borrado. Caprichava, esforçava-me, mobilizava toda a minha paciência, e no fim a pena obedecia aos meus pobres nervos, e a tinta marcava-me a condenaçấo ao bolo. (REGO, 1994, p. 3, 4, 17, 27)

Até os meus 5 anos, que é a época que estamos chamando de primeira infância, estava na Escola AR, nessa fiz o maternal, jardim 1 e 2 . Foi uma época sem dúvida maravilhosa, de mil e uma descobertas e que deixou muitas saudades. Entrei na escola AR com três anos de idade lembro que tinha uma biblioteca com vários livros infantis e depois de pegarmos livros fazíamos algumas tarefinhas com ele como por exemplo desenhe os personagens. Até hoje tenho contato com a minha $1^{\text {a }}$ professora quando a encontro é uma emoção muito grande, ela me disse que sempre fui muito esforçada, participava da aula. 
$[\ldots]$

Minha mãe me contou que quando eu era pequena, gostava de ir para a escola, quando não ia chorava, e que nas reuniôes da escola só tinha elogios. [...]

A primeira infância é fase da descoberta, das novidades, uma fase mágica e que deixa muita saudade.

(Texto autobiográfico de uma aluna, Alice, do $1^{\circ}$ ano do Ensino Médio, produzido em 2008; compóe o corpus de dados da pesquisa "Memória de leitores: uma história construída na trama dos discursos")

Ricoeur (2007, p. 73) considera que, com

[...] a rememoração, enfatiza-se o retorno à consciência despertada de um acontecimento reconhecido como tendo ocorrido antes do momento em que esta declara tê-lo sentido, percebido, sabido. A marca temporal do antes constitui, assim, o traço distintivo da recordação, sob a dupla forma da evocaçáo simples e do reconhecimento que conclui o processo de recordaçáo.

Os episódios narrados nos textos de Cora Coralina, José Lins do Rego e Alice configuram esse processo de rememoração e materializam o que Bakhtin (2003, p. 138) entende por biografia ou autobiografia (descrição de uma vida), ou seja, "a forma transgrediente imediata em que posso objetivar artisticamente a mim mesmo e minha vida". Ao produzir tais enunciados, a poeta, o romancista e a aluna, com efeito, estetizam as suas histórias de vida, mas o fazem a partir da rememoração ou da construção de memórias de acontecimentos por eles vivenciados.

Discutindo a (auto)biografia como gênero do discurso, Bakhtin considera, por um lado, que "nem na biografia, nem na autobiografia o eu-para-si (a relação consigo mesmo) é elemento organizador constitutivo da forma” (BAKHTIN, 2003, p. 138-139), e por outro, que o valor biográfico pode organizar "o vivenciamento da própria vida e a narração sobre a minha vida, pode ser forma de conscientização, visão da minha própria vida” (BAKHTIN, 2003, p. 139). Assim, guardada a distância que separa a posição autor da posição personagem, "na biografia o autor está mais próximo do herói desta, os dois como que podem trocar de lugar, e por essa razão é possível a coincidência pessoal entre personagem e autor além dos limites do todo artístico" (BAKHTIN, 2003, p. 139).

Essas consideraçóes me permitem, portanto, tomar os enunciados que selecionei como produçóes que se acham no entre-lugar, deslizando 
no limite entre a ficção, a memória e a história. Obviamente, não a história tradicional, mas aquela conhecida como nova história, justamente por ser "escrita como reação deliberada contra o 'paradigma tradicional", a que tem por base filosófica a "idéia de que a realidade é social ou culturalmente construída" é a "história vista de baixo" (BURKE, 1992, p. 10-12). Tais enunciados assumem, aqui, o status de testemunho, porque materializam as condiçôes sócio-históricas em que viveram os seus enunciadores.

Como produção autobiográfica, de caráter memorialístico, esses textos são um exercício de "escrita de si", uma maneira de "mostrar-se, dar-se a ver, fazer aparecer o próprio rosto junto ao outro" (FOUCAULT, 1992, p. 150). Como testemunhos, adquirem confiabilidade, pois os enunciadores nomeiam a si mesmos, por meio da autodesignação que, conforme Ricoeur, é pontuada por um triplo dêitico: "A primeira pessoa do singular, o tempo passado do verbo e a menção ao lá em relação ao aqui”. A autodesignação instaura uma situação dialogal, é como se o enunciador, ao testemunhar, dissesse "Eu estava la”" e acrescentasse "Acreditem em mim" (RICOEUR, 2007, p. 172-173).

O fragmento do primeiro poema de Cora Coralina inicia-se com uma frase - "Muito me valeu a escola" - em que se acham os três aspectos da autodesignação: a primeira pessoa do singular, marcada no pronome me; o verbo no tempo passado - valeu; e o estabelecimento da relação entre o lá e o aqui. Quem faz as declaraçôes não é Aninha, é Cora. Aninha está lá, no passado, vivendo o seu tempo. Cora está aqui, no seu tempo presente, testemunhando para o tempo presente de cada leitor o que vivera como Aninha. Esses três aspectos se encontram materializados linguisticamente nos dois poemas que analiso.

Na narrativa de J. L. do Rego, dá-se ocorrência semelhante. O narrador se designa pela marca da primeira pessoa: "Eu, encolhido numa cadeira, todo enfiado para um canto, o meu tio Juca e o mestre". A não ser nas situaçốes de diálogo, momento em que o narrador situa as personagens lá, no tempo presente delas que se contrapóe tanto ao aqui de quem narra quanto ao de quem lê o narrado, os verbos flexionam-se no passado. Passados e presentes se sobrepóem, envolvendo narrador, personagens e leitores na complexa rede do tempo. Na verdade, o autor J. L. do Rego parte do presente de Carlos de Melo para produzir o passado de Carlinhos e traçar sua trajetória autobiográfica.

Também Alice, em sua narrativa, produz o efeito da autodesignação, por meio desses recursos linguísticos. Ela se nomeia como primeira pessoa, utilizando pronomes e desinências verbais: "Até os meus 5 anos"; "Entrei na 
escola AR com três anos de idade"; "Ela me disse". Predominam os verbos no tempo passado. A relação entre o aqui e o lá é bem marcada, especialmente em uma passagem em que o leitor é transportado do tempo da narrativa para o tempo da escritura, ou seja, o presente da narradora: "Até hoje tenho contato com a minha $1^{\text {a }}$ professora quando a encontro é uma emoção muito grande".

A autodesignaçáo confere fidedignidade ao testemunho que, como enunciado, está repleto

[...] dos ecos e lembranças de outros enunciados, aos quais está vinculado no interior de uma esfera comum da comunicaçáo verbal. O enunciado deve ser considerado acima de tudo como uma resposta a enunciados anteriores dentro de uma dada esfera (a palavra "resposta" é empregada aqui no sentido lato): refuta-os, confirma-os, completa-os, baseia-se nele, supóe-nos conhecidos e, de um modo ou de outro, conta com eles. (BAKHTIN, 2003, p. 316)

Materializa-se, portanto, nesses enunciados que são memórias, algo da história da escola. Souza (2000) lembra que a escola primária, em seu início, teve como objetivo principal recristianizar o povo, ensinando o catecismo. Com a instituição da escola pública, as práticas e os rituais da escola religiosa foram laicizados; criou-se, entâo, uma espécie de moralidade cristã sem menção à religiáo. No século XIX, a experiência francesa influenciou sobremaneira o ensino no Brasil. Só mais tarde, já no século XX, é que o pragmatismo da experiência estadunidense veio performar as práticas didático-pedagógicas em terras brasileiras.

A moral cristá, especialmente a pregada pela Igreja Católica, instituiu a submissão ao suplício e ao sacrifício como forma de alcançar o conhecimento, a educação e o aprimoramento da natureza humana. Ainda que a escola pública tenha pretendido laicizar-se, ela continuou determinada pelas práticas da moral católica. Essas práticas expressam-se nas memórias da poeta e do romancista, conforme se constata nas seguintes passagens, entre outras:

Um dia, certo dia, a mestra se impacientou.

Gaguejava a lição, truncava tudo. Não dava mesmo.

A mestra se alterou de todo, perdeu a paciência,

e mandou enérgica: estende a máo

[...]

e o bolo estralou na pequena máo obediente.

(CORALINA, 2004) 
O colégio de Itabaiana criara fama pelo seu rigorismo. Era uma espécie de último recurso para meninos sem jeito. [...] Lá estiveram os meus primos uns dois anos. Voltaram contando as mais terríveis histórias do diretor. Um judeu. Dava sem pena de palmatória, por qualquer coisa. Era ali onde estava agora. (REGO, 1994)

Encontra-se aí a expressão marcante do constrangimento vivenciado pelos dois autores diante da ameaça do castigo, que tinha por fim fazê-los progredir nos estudos. Como instituiçáo que nascera das entranhas da Igreja, à escola, durante muito tempo de sua história, foi conferida autoridade superior ou igual à dos pais. Ao professor competia usar os recursos necessários para que o aluno aprendesse. Esses recursos quase que se restringiam aos castigos físicos e morais. $\mathrm{O}$ que era considerado natural para uma época em que a criança ainda não era considerada "gente" e, para torná-la gente, era preciso discipliná-la, educá-la com rigor.

O espírito científico do Iluminismo povoou a emergente instituição escolar pública e preconizou um ensino que se contrapusesse àquele que privilegiava o aprendizado por meio da memorização. Desejou-se que o aprendiz fosse submetido a uma pedagogia ativa, que dominasse os processos, os métodos, as lógicas da descoberta e a crítica científica. Contudo, assevera Foucault (2007, p. 183), essas mesmas "luzes que descobriram as liberdades inventaram também as disciplinas". Estas, aqui entendidas não como o estudo de um ramo do saber, mas como "a arte do corpo humano, que visa não unicamente o aumento de suas habilidades, nem tampouco aprofundar sua sujeição, mas a formaçáo de uma relação que no mesmo mecanismo o torna tanto mais obediente quanto é mais útil, e inversamente" (FOUCAULT, 2007, p. 119).

Era certamente com o nobre objetivo de aumentar as habilidades de seus alunos que os mestres do século XIX e início do século XX os submetiam aos flagelos pedagógicos. Ressalto que o que nomeio como flagelo pedagógico era entendido, entấo, como procedimentos necessários ao aprendizado do aluno. E se os praticavam, não o faziam senão por nobreza, pois era nisso que se acreditava. Baptista (2003) faz referência a Philippe Ariès - mesmo considerando as críticas à fragilidade teórica de suas pesquisas -, para lembrar que durante a Idade Média era muito comum que as crianças vivessem "a primeira infância não sob o olhar atento e vigilante dos pais ou de adultos cumprindo esta função, mas de forma 
que se confundiam com os animais - vale ressaltar que criança, em sua etimologia, está referida em creantia, particípio presente de creare, vinculada ao animal que se está criando".

Entendida dessa forma, era compreensível que a infância fosse objeto da mais rigorosa disciplina, como meio de torná-la dócil e útil, submissa e educada, capaz de repetir o que lhe fosse ensinado. E quando não era capaz, o que lhe restava era, no mínimo, o bolo de palmatória. Parece contraditório que os mesmos ideais iluministas que pretenderam ampliar culturalmente os horizontes da criança, a fim de colocá-la, por meio da ciência e da razão, em contato com a cultura universal ligada ao humanismo, tenham também engendrado a fabricação de corpos submissos e exercitados. A aparente contradição se esvai ante a evidência da relação entre Iluminismo, humanismo e liberalismo: vertentes filosóficas que acreditaram ser exequível o famoso par cartesiano "ordem e progresso".

Em nome dessa ordem e desse progresso, instaurava-se o terror nas escolas. A ciência e a razão adentraram o ambiente escolar sem conseguir romper com práticas semelhantes às dos suplícios medievais, que marcavam o corpo insubmisso. Ao contrário, o paradigma científico que irrompe durante a Idade Moderna serve-se dessas práticas como um meio para se estabelecer. Determinados por esses discursos e práticas, que se contrapóem e se complementam, os professores são autorizados a "educar" e a "ensinar" pela condenação ao castigo, como declaram Cora Coralina e J. L. do Rego:

Aninha, estende a mão. Mão de Aninha, tão pequena.

A palmatória cresceu no meu medo, seu rodelo se fez maior,

$\mathrm{O}$ cabo se fez cabo de machado, a mestra se fez gigante

e o bolo estralou na pequena mão obediente.

Meu berro! e a mijada incontinente, irreprimida.

(CORALINA, 2004)

- Se este caderno vier borrado amanhã, o senhor se arrepende.

E ia borrado. Caprichava, esforçava-me, mobilizava toda a minha paciência, e no fim a pena obedecia aos meus pobres nervos, e a tinta marcava-me a condenação ao bolo. (REGO, 1994)

Constata-se, lendo essas narrativas, as asserçóes de Souza (2000, p. 30) sobre a cultura escolar: 
[...] sendo mais impositiva que sedutora, explicitando cruamente em vez de sugerir, criava jogos de adesão e de crítica em relação a si mesma, e, mais amplamente, à cultura maior que lhe servia de respaldo e que devia transmitir. Da sua violência e parcialidade advinha o efeito de fazer tanto os indivíduos internalizarem a cultura quanto torná-la objetiva; criava assim possibilidades múltiplas de os indivíduos se posicionarem de diferentes formas em relaçáo a ela. Pois, no limite da herança iluminista, a autonomia do indivíduo supunha, na verdade, a superação da própria cultura escolar.

Cora Coralina e J. L. do Rego, como personagens de suas narrativas, posicionam-se, eles mesmos, de formas diferentes em relação à escola. No primeiro poema citado, a poeta declara: "Muito me valeu a escola". Nesse verso, configura-se uma posiçáo da enunciadora em relaçáo à escola, que parece não encontrar eco nas demais declaraçôes feitas por ela e que mais parecem uma confissão de todo sofrimento, de todo constrangimento, de toda a vergonha que sofrera. No entanto, no poema seguinte, a poeta ratifica essa posição de reconhecimento do valor da escola:

Minha escola primária, fostes meu ponto de partida, dei voltas ao mundo.

Criei meus mundos...

Minha escola primária. Minha memória reverencia minha velha Mestra. [...]

Minha escola primária...

Eu era um casulo feio, informe, inexpressivo.

E ela me refez, me desencantou.

Abriu pela paciência e didática da velha mestra, cinquentanos mais do que eu, o meu entendimento ocluso.

(CORALINA, 2004)

Carlinhos, personagem de que se serve J. L. do Rego para construir suas memórias, apesar de mais resistente, reconhece que

$\mathrm{O}$ velho Maciel tinha razão. Em pouco tempo adiantara-me bastante. $\mathrm{O}$ medo do bolo vencera o rude da d. Sinhazinha. Estava nas frações e quase no fim do terceiro livro de leitura. A letra, porém, é que não tinha jeito de melhorar. O meu nervoso talvez fosse o responsável pelos meus garranchos. Cobria com cuidado os cadernos de caligrafia, e borróes ficavam em cada página. (REGO, 1994) 
A escritura desses textos, ou melhor, a produção discursivo-literária desses autores, que lhes conferiu renome e reconhecimento, atesta o que Souza (2000) afirma sobre a superação do indivíduo em relação à cultura escolar. Apesar da violência pedagógica a que foram submetidos, ou em virtude dela mesma, esses indivíduos constituem-se sujeitos, assumem a posiçáo-autor e podem posicionar-se em relação à cultura escolar que os constituiu. Fica, realmente, a impressão de que, não fossem esses conflitos desenrolados no palco escolar, não haveria memórias a construir.

Ao enunciar o momento da vaia de que foi vítima - "Só? Não. O coro do banco dos meninos, a vaia impiedosa. I - Mijou de medo... Mijou de medo... Mijou de medo..." -, a poeta materializa outro aspecto da memória da escola: a sala de aula dividida, o lado dos meninos, o lado das meninas; o banco dos meninos, o banco das meninas. Isso, quando a escola não era realmente toda só para meninos ou só para meninas, o que foi muito comum até a década de 1970 e que não deixou de existir completamente. Nos fragmentos que apresento da narrativa de J. L. do Rego, não há referência a essa separação, mas há passagens do referido romance em que o narrador conta sobre a presença de meninas na escola. Elas ficavam, também, separadas dos meninos e em volta do professor.

Separando grupos e indivíduos, delimitando espaços, segregando meninos e meninas, a escola acreditou - ou continua acreditando? - que melhor governaria, inclusive, as manifestaçôes da sexualidade infantil e adolescente. Ou seja, a própria instituição remete o aluno para o fato de que sua sexualidade existe, precoce, ativa e permanente; por isso, precisa ser vigiada, governada. Encontram-se novamente, aqui, atravessados os discursos e as práticas da Igreja como instituição responsável pela preservaçáo moral dos indivíduos. Ao invés de promover o silenciamento que desejava acerca da sexualidade, a escola, ao se preocupar excessivamente em controlá-la, acaba por incitá-la.

Muito apropriadamente, Souza (2000) anuncia que a relação entre memória e escola é mais profunda, vai além da história e da nostalgia. A pesquisadora, citando Hanna Arendt, diz que

[...] a cultura escolar é testamentária. Antes de tornar as crianças felizes, antes de proporcionar seu desenvolvimento, sua funçáo é dizer aos herdeiros o que será seu de direito, é legar posses do passado para o futuro. Sem testamento cultural e sem escola - que indique, que selecione e nomeie, que transmita e preserve, que fale onde se encontram os tesouros e qual o seu valor - não pode existir continuidade consciente do tempo, e portanto, em 
termos humanos, nem passado nem futuro. Pode-se questionar a herança no todo ou em parte, deve-se alargar o círculo dos herdeiros. Mas náo se pode negar que esta transmissão do capital cultural tenha razão de existir. (ARENDT 1971 apud SOUZA, 2007, p. 41)

Esses pressupostos da cultura escolar e de seus herdeiros encontram-se configurados nos enunciados da poeta e do romancista. Os dois reconhecem que a escola cumpriu sua função, transmitindo-lhes seu capital cultural, ainda que a duras penas para eles. Cabem, agora, as questôes: que mudanças terão ocorrido na escola, na família, na sociedade, entre os inícios do século XX e do século XXI, a ponto de determinar a efetivação de enunciados como os produzidos pela aluna Alice? Que condições sócio-históricas permitiram a emergência de tais enunciados? A contemporaneidade nos assalta com contradiçóes e complexidades acentuadas. A escola pública, prometida como via de acesso das classes populares ao mercado de trabalho e, consequentemente, a melhores condiçóes de vida, manteve-se sempre tấo distanciada das realidades sociais que pouco conseguiu atender dessa demanda.

A família assumiu configuraçóes diferentes das tradicionais, perdeu o referencial de limite e educação dos filhos, tarefa que tem transferido para a instituição escolar. A sociedade globalizou-se, assumiu ares de futuro: vivemos o tempo da urgência, do espetáculo, do consumo. Quem não dá conta desse ritmo é excluído e são muitos os excluídos. Parte deles está na escola que, não podendo mais se servir dos antigos meios de submissão e castigo e não conseguindo promover um ensino significativo para esses alunos, tem se tornado palco para o que Souza (2000, p. 11) chamou de "barbárie". A violência deixou de ser apenas pedagógica.

Mas as mesmas práticas e os mesmos discursos que foram atravessando a escola, a família, a sociedade, conferindo-lhes características que poderiam ser compreendidas como negativas, produziram mudanças e resultados que podem ser entendidos como positivos. Os avanços e a vulgarização dos estudos sociológicos, psicológicos e linguísticos adentraram a escola, e, se por um lado muitas vezes fizeram os professores sentir que estavam sem "chão", por criticar-lhes o excessivo conservadorismo e convencionalismo, e propor-lhes a aplicação de teorias para as quais não foram preparados, por outro promoveram a reflexáo e a investigaçáo sobre o ato de ensinar e o processo de aprendizagem. 
A criança, saindo da condição de "não-ser" para a de "ser em potencial", passa a constituir objeto e fim de estudos e pesquisas na área pedagógico-educacional. Ela, agora, vai para a escola entre os 3 e 4 anos. Essa etapa pré-escolar - maternal e jardim - é toda voltada para aquilo que se acredita serem as características e os interesses da criança na primeira infância. Nas etapas seguintes, a tradicional organizaçáo do espaço físico, os processos de exame e avaliação, o predomínio da didática da informação e da exposição passam a conviver com as concepçóes que defendem que o aluno deve ser o construtor do próprio conhecimento.

As questôes de direitos da infância e da adolescência são definidas em documentos, na forma de leis, como o Estatuto da Criança e do Adolescente (BRASIL, 1990). As puniçôes, os castigos impingidos ostensivamente ao corpo deveriam, entáo, entrar para os arquivos da memória. Nem mesmo aos pais eles são permitidos. Se isso despojou a escola de certos mecanismos de controle, em alguns casos acabou por produzir um ambiente em que a criança sente prazer em estar e se sente estimulada para aprender. A escola perde um pouco do seu caráter austero e passa a se "enfeitar" para receber a criança. O mercado de livros, de materiais e acessórios escolares investe fortemente nos consumidores infanto-juvenis.

A psicologia moderna defende que a criança se desenvolve brincando, experimentando. No entanto, esses novos discursos e práticas não se instauraram de repente nem substituíram completamente aqueles que consideravam a criança como um "não-ser", ou como um adulto em miniatura. Ora a instituição escolar avança e se apoia em teóricos, psicólogos e pedagogos como Pestalozzi, Montessori, Piaget, Vygotsky, dentre outros, ora ela se mantém inflexível na sua postura tradicional de dona e transmissora do conhecimento, disciplinadora de corpos e mentes.

Práticas e discursos tradicionais ou progressistas imbricados configuram a sociedade contemporânea que se especializou no controle (DELEUZE, 1992) do sujeito por meio de mecanismos de tal forma eficientes que a eles não se pode escapar. $\mathrm{Na}$ sociedade do controle, entra em vigor o que Foucault (2001) chamou de biopoder, ou seja, "aquilo que faz entrar a vida e seus mecanismos no domínio dos cálculos explícitos e faz do poder-saber um agente de transformação da vida humana" (SOUSA, 2008, p. 99). É um modelo de sociedade em que há excessiva preocupação com o bem-estar, com as necessidades das pessoas que são, por assim dizer, "obrigadas" a ser felizes. 
Não se pode negar a convivência entre os discursos controversos que produzem tanto o fracasso da escola quanto a ideia de que a escola é a redentora das misérias e ignorância humanas. A compreensão de que a instituição escolar deveria garantir aos alunos o acesso aos bens culturais e materiais por meio do conhecimento e da formação profissional -, tâo caros ao que se considera "felicidade", promoveu mudanças nos discursos educacionais e nas práticas pedagógicas. Discursos e práticas, de certa forma, suavizaram-se para controlar, mais do que disciplinar; para seduzir, mais do que submeter. Assim, entende-se porque Alice, diferentemente de Cora Coralina e J. L. do Rego, enuncia uma escola que lhe é uma grata memória, lembrança de momentos de prazer e encantamento.

Pelos enunciados efetivados na narrativa de Alice, pode-se supor que a escola em que ela estudara na primeira infância concebia a educação similarmente ao que concebe Morin (2002, p. 39), quando afirma que a "educação deve favorecer a aptidão natural da mente em formular e resolver problemas essenciais e, de forma correlata, estimular o uso total da inteligência geral. Este uso total pede o livre exercício da curiosidade, a faculdade mais expandida e a mais viva durante a infância e a adolescência”. Em um ambiente que estimula o uso da inteligência e incita a curiosidade, o aluno subjetiva-se como construtor de si mesmo e do próprio conhecimento, e essa experiência pode acabar por constituir-se num exercício de relativa liberdade.

\section{Passado e futuro: arquivos presentes da memória escolar}

Concepções de ensino e educação com caráter mais libertário são tecidas em determinadas condiçóes históricas que possibilitam a emergência de novos discursos e práticas que, embora permaneçam entrelaçados aos discursos e às práticas tradicionais, são fios a (des)compor outras estampas nessa rede discursiva. A saturação de modelos vigentes produz as condições para que diferentes enunciados se efetivem. É assim que compreendo os pensamentos de Morin (2001, 2006) e Santos (2000, 2001): como reação a um paradigma de racionalidade, de educação, de conhecimento, de ciência que já não dá conta da complexidade social contemporânea.

Ao postular que a educaçáo deve enfrentar o problema do erro e da ilusão e mostrar que o conhecimento é, em algum grau, por ele ameaçado; 
ao considerar que o conhecimento científico não pode prescindir do senso comum e dos estudos humanísticos, esses pensadores enunciam uma nova racionalidade que já vinha sendo constituída no bojo da racionalidade cartesiana e que, por isso, dela também não pode prescindir. Nessa relação dialógica (BAKHTIN, 1990) entre tradição e inovação situo a escola que proporcionou a Alice uma experiência tão diferente da de Cora Coralina e J. L. do Rego.

Contudo, é preciso não esquecer que a experiência de Alice é uma das possíveis realidades configuradas no ambiente escolar. Se tantas outras podem a ela se assemelhar, muitas, talvez a maioria, dela vão divergir. Conforme afirma Morin (2001), a história não constitui uma evolução linear, ela é um complexo de ordem, desordem, organização e, eu acrescentaria, desorganização. Ou seja, o mesmo discurso que produz a ordem e a organização pode produzir a desordem e a desorganização. A história da escola se materializa nessa superfície áspera em que ditos e contraditos se relacionam, se confrontam, se entrelaçam e se refratam. A escola configurada no texto de Alice não exclui a escola de Cora nem a de J. L. do Rego, pelo contrário, acrescenta-se a elas, enriquecendo o arquivo das memórias escolares.

\section{Referências}

ARENDT, H. Entre o passado e o futuro. São Paulo: Perspectiva, 1972.

BAKHTIN, M. (VOLOCHINOV). Marxismo e filosofia da linguagem. São Paulo: Hucitec, 1990. . Estética da criação verbal. São Paulo: Martins Fontes, 2003.

BAPTISTA, V. F. Amar, cuidar, subjetivar: implicaçóes na primeira infância. Estilos clin., São Paulo, v. 8, n. 15, 2003. Disponível em: <http:// www.revistasusp.sibi.usp.br/scielo.php? script=sci_arttext\&pid=S1415-71282003000200005\&lng=pt\&nrm=iso>. Acesso em: 16 jul 2009.

BURKE, P. Abertura: a nova história, seu passado e seu futuro. In: BURKE, P. (Org.) A escrita da História: novas perspectivas. Tradução de Magda Lopes. São Paulo: Editora UNESP, 1992. 
BRASIL. Estatuto da criança e do adolescente: Lei n. 8069, de 13 de julho de 1990, Lei n. 8242 de 12 de outubro de 1991. - 3. ed. - Brasília: Câmara dos Deputados. Coordenação de Publicaçóes, 2001. Disponível em: <http:// apache.camara.gov.br/portal/arquivos/Camara/internet/publicacoes/estatutocrianca.pdf>. Acesso em 20 jul 2009.

CORALINA, C. Melhores poemas. São Paulo: Global, 2004.

DELEUZE, G. Conversaçôes. São Paulo: Ed. 34, 1992.

FOUCAULT, M. O que é um autor? Lisboa: Passagens, 1992.

. História da sexualidade I: a vontade de saber. Rio de Janeiro: Graal, 2001.

. Vigiar e punir: o nascimento da prisão. Petrópolis, RJ: Vozes, 2007.

. A arqueologia do saber. 7. ed. Rio de Janeiro: Forense Universitária, 2004 .

HALBWACHS, M. A memória coletiva. São Paulo: Vértice, 1990.

MORIN, E. Os sete saberes necessários à educação do futuro. 5. ed. São Paulo: Cortez; Brasília: Unesco, 2002.

- A noção de sujeito. In: A cabeça bem-feita: repensar a reforma, reformar o pensamento. 12. ed. Rio de Janeiro: Bertrand Brasil, 2006.

REGO, J. L. do. Doidinho. Rio de Janeiro: José Olympio, 1994.

RICOEUR, P. A memória, a história, o esquecimento. Campinas, SP: Editora da Unicamp, 2007.

SANTOS, B. Da idéia de universidade à universidade de idéias. In: SANTOS, B. de S. Pela mão de Alice: o social e o político na pós-modernidade. 7. ed. São Paulo: Cortez, 2000. p. 187-233.

. O discurso sobre as ciências. 12. ed. Porto, Portugal: Ediçóes Afrontamento, 2001.

SOUSA, K. M. de. O cuidado de si na prática educativa: a resistência na sociedade da visibilidade. Solta a Voz, Goiânia, v. 19, n. 1, p. 93-109, jan./ jun. 2008. 
428 Polyphonía, v. 21/2, jul./dez. 2010

SOUZA, M. C. C. C. de. Escola e memória. Bragança Paulista, SP: IFAN-CDAPH. Editora da Universidade São Francisco/EDUSF, 2007.

Recebido em: 28 jan. 2011

Aceito em: 10 abr. 2011 